\title{
LOW COST WIRELESS ECG PATCH USING ESP32
}

\author{
Budi Sugandi", Muhammad Haikal Satria ${ }^{\#}$, Hamdani Arif", Nelmiawati", Indra Hardian \\ Mulyadi* $^{*}$ \\ *Politeknik Negeri Batam \\ Department of Electrical Engineering \\ Batam Centre, Jl. Ahmad Yani, Batam 29461, Indonesia \\ E-mail: indra@polibatam.ac.id \\ \#PT. Macan Teknologi Asia \\ Batam Centre, Jl. Raja H. Fisabilillah, Batam 29444, Indonesia \\ E-mail: admin@macantech.asia
}

\begin{abstract}
Abstrak
Elektrokardiograf (ECG) yang bersifat wearable dan nirkabel telah banyak digunakan untuk monitoring jangka panjang karena alasan praktis. Selain Signal to Noise Ratio (SNR) yang tinggi, salah satu manfaat ECG dalam bentuk patch adalah fleksibilitasnya bagi pengguna dalam menempatkan elektroda. Sebagian besar ECG patch nirkabel komersial yang ada di pasaran hanya dapat menampilkan Heart Rate Variability (HRV) saja, tanpa kemampuan untuk menyediakan atau merekam gelombang EKG. Beberapa produk komersial menggunakan dua elektroda saja: Right Arm (RA) dan Left Arm (LA), tanpa elektroda tambahan yang disebut Right Arm Drive (RLD). Selain itu, menyediakan lebih dari satu opsi teknologi nirkabel untuk ECG patch merupakan keuntungan tambahan. Pada penelitian ini, kami membuat ECG patch nirkabel berbiaya rendah yang memiliki kemampuan untuk menyediakan bentuk gelombang EKG (Lead I) dan menghitung HRV secara otomatis. Selain RA dan LA, alat ini menggunakan elektroda RLD untuk meningkatkan Common Mode Rejection Ratio (CMRR). Untuk pemrosesan data, kami menggunakan ESP32, mikrokontroler 32-bit berdaya rendah yang dilengkapi dengan Bluetooth Classic (BT), Bluetooth Low Energy (BLE), dan Wifi dalam modul yang ringkas. Hasil tes menunjukkan bahwa ECG patch yang dibuat menghasilkan perhitungan HRV yang lebih akurat serta waktu transisi 2,7 kali lebih cepat dibandingkan dengan produk komersial yang kami jadikan referensi.
\end{abstract}

Kata kunci: Elektrokardiograf wearable, patch, ESP32, heart rate variability

\begin{abstract}
Wearable-and-wireless Electrocardiograph (ECG) has been widely used for long term monitoring due to practical reasons. Besides its high Signal to Noise Ratio (SNR), one of patch benefits is its flexibility for users to place the electrodes. However, most of existing commercial wireless ECG patches displays Heart Rate Variability (HRV) only, without ability to provide or record the ECG waveform. Some of them employ two electrodes only: Right Arm (RA) and Left Arm (LA), without additional electrode called Right Arm Drive (RLD). In addition, It is beneficial to provide more than one wireless technology option for ECG patch. We propose a low cost wireless ECG patch that has ability to provide ECG waveform (Lead I) and calculate HRV automatically. Besides RA and LA, it utilized RLD electrode to increase Common Mode Rejection Ratio (CMRR). For data processing, we employed ESP32, a low-power 32-bit microcontroller equipped with Bluetooth Classic (BT), Bluetooth Low Energy (BLE), and Wifi in a compact module. The test results showed that the proposed ECG patch resulted in more accurate HRV calculation as well as 2,7 times faster transition time compared to a commercial product.
\end{abstract}

Keywords: Wearable electrocardiograph, patch, ESP32, heart rate variability

\section{Introduction}

Cardiovascular Disease (CVD) caused 17.3 million of deaths in the world [1], including 2.6 million of Indonesian people [2]. For preventative treatment and early diagnosis, a 24-hour monitoring is required. Long term monitoring is necessary because of the difficulty to predict when heart abnormality occurs [3]. Electrocardiograph machine (ECG) has been still a standard to measure heart electrical signal through 


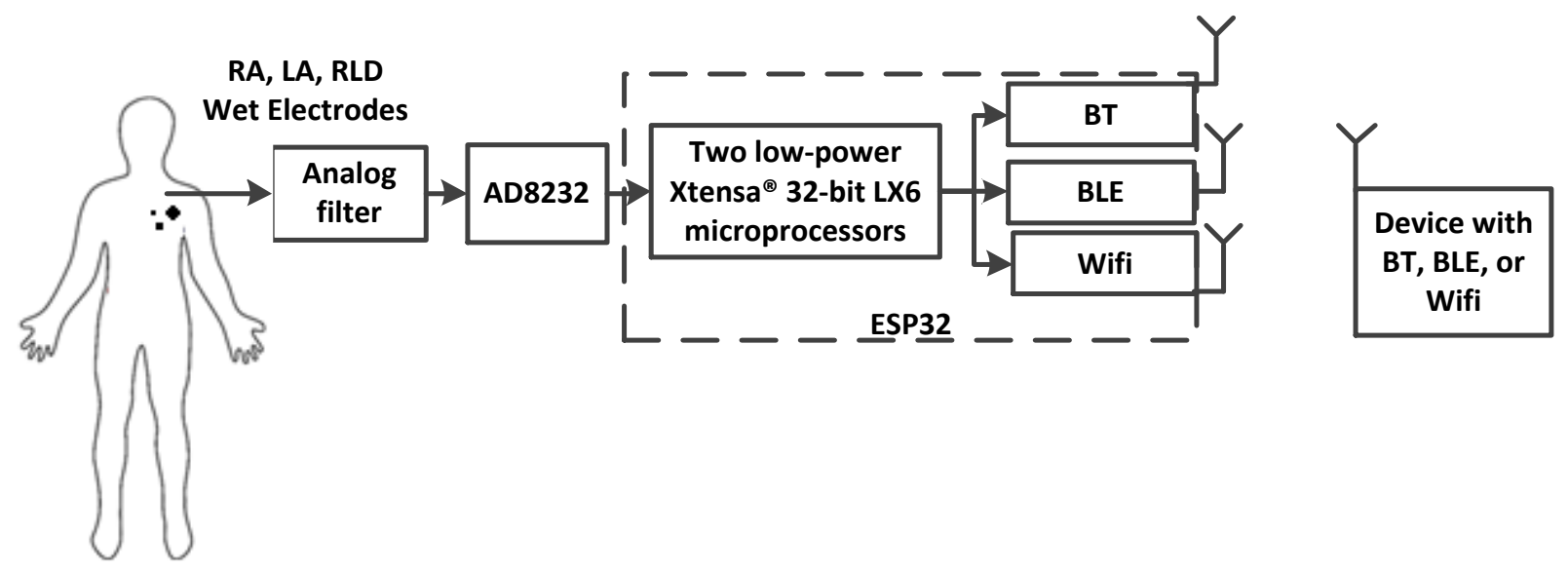

Figure 1: System block diagram

skin surface. For practical reason, wearable ECGs have been widely used, such has patch [4], strap [5], smart watch [6], and shirt [7].

One of patch benefits is its flexibility for users to place the electrodes, unlike strap, watch, and shirt. Its flexibility is very useful since the optimal location of electrodes depends on ECG segment (i.e. P, Q, R, S, and $\mathrm{T}$ ) and type of heart disease [8]. The optimal electrode location is also different for each person. By using ECG patch, users may also place the electrodes wherever they feel convenient.

Wearing ECG patch means utilizing wet electrodes. Besides resulting in good quality signal, the wet adhesive electrodes are advantageous to hold the ECG patch attached on skin. Commonly, the ECG patches are wireless. Type of the wireless technology must be selected based on its popularity, i.e. widely used by people for daily use.

Most of existing commercial wireless ECG patches displays Heart Rate Variability (HRV) only, without transmitting or recording the ECG waveform. For prognosis, this waveform is necessary. Besides that, displaying of the ECG waveform is also important to ensure the signal captured by the device is 'good enough', e.g. having high Signal to Noise Ratio (SNR), so that the HRV calculation is accurate.

For practical reasons, most of existing wireless ECG patches employ two electrodes only: Right Arm (RA) and Left Arm (LA), without additional electrode called Right Arm Drive (RLD). Absence of RLD may cause low Common Mode Rejection ratio (CMRR) since the biopotential amplifier is basically a differential amplifier. RLD is very crucial to increase the CMRR.

Existing commercial wireless ECG patches utilizes single type of communication; however, it is beneficial to provide more than one option. Hence, users have flexibility to choose appropriate type of wireless communication based on network availability. Based on those reasons, we propose a low cost wireless ECG patch that has ability to send ECG waveform (Lead I) and calculate HRV automatically. It utilizes three electrodes (RA, LA, and RLD) to increase CMRR. For data processing, we used is ESP32, a low-power 32-bit microcontroller equipped with Bluetooth Classic (BT), Bluetooth Low Energy (BLE), and Wifi in a compact module.

\section{Method}

\section{A. System}

Block diagram of the ECG patch is shown in Figure 1. The ECG patch consists of analog filter (resistors and capacitors), a single-channel biopotential amplifier (AD8232ACPZ-R7), ESP32 WROOM, and a rechargeable $3.7 \mathrm{~V}$ lithium battery.

Physically, the ECG patch consists of three main parts which are connected each other through two $35 \mathrm{~mm}$ flexible 'bridges' (Figure patch). ESP32, analog and AD8232, and lithium battery are located separately. Each part contains a snap at the backside to attach the wet electrode.

The proposed ECG patch is designed to be attached on skin surface of the torso (Figure Indra). Three wet electrodes were employed to hold the ECG patch. The electrodes are attached through three snaps. Users may use any size or brand of commercial disposable wet electrodes. They can also change the electrodes periodically. Compared to dry or non-contact electrodes, wet electrodes are still a 'gold standard' in ECG measurement due to their high SNR.

Electrical heart signal on skin surface was acquired by the wet electrodes and the filtered. The filtered signal was then amplified (with gain of 100) by using AD8232. The amplified analog signal was then converted to digital by a 12-bit Analog to Digital Converter (ADC) built in ESP32 and then processed. ESP32 contains two low-power Xtensa ${ }^{\circledR}$ 32-bit LX6 


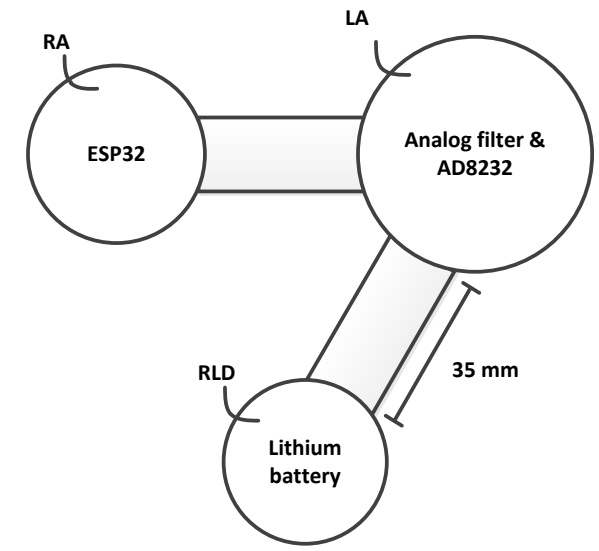

Figure 2: Parts of the ECG patch

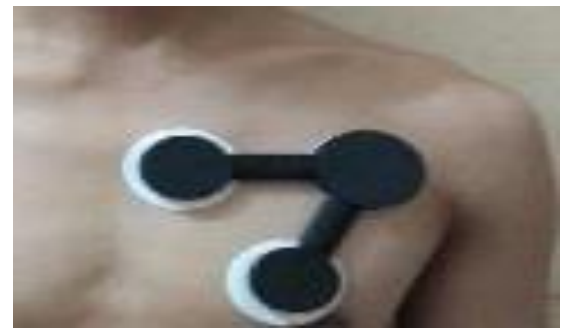

Figure 3: The ECG patch attachment on skin surface

microprocessors, which may run up to 600 Dhrystone Million Instructions per second (DIMPS), quite fast for ECG signal processing.

\section{B. HRV Calculation}

HRV was calculated by using (1) RR_Interval is time interval between two consecutive $\mathrm{R}$ peaks. Instead of complex algorithm, like Pan-Tompkins [9], we implemented filter-based algorithm to detect $\mathrm{R}$ peak as presented in [10]. The algorithm consists of three steps: High Pass Filter (HPF), Low Pass Filter (LPF), and Decision Making (DM). ECG sampling was $200 \mathrm{~Hz}$, which means time interval between samples is $5 \mathrm{~ms}$.

$$
H R V=\frac{60000}{R R_{-} \text {Interval }}
$$

.The HPF was performed using (2), where $x[n]$ is input data of sample $n, y[n]$ is the filtered signal, and $M$ is the filter length. In this work, we set $M$ to 5. $y[n]$ was then low pass filtered using (3) resulting in $z[n]$. In this paper, $k$ was set to 30 .

$$
\begin{gathered}
y[n]=x\left[n-\frac{M+1}{2}\right]-\frac{1}{M} \sum_{m=0}^{M-1} x[n-m] \\
z[n]=\sum_{k=0}^{k-1} y^{2}[n-k]
\end{gathered}
$$

After high pass filtered, the DM detected R peak by using (4), (5), and (6). Threshold was adaptive, and this makes the algorithm more resistant to base line variation. In this paper, we set $\alpha$ and $\gamma$ to 0.05 and 0.175 respectively.

$$
\begin{gathered}
\text { if } z[n] \geq \text { Threshold } \rightarrow \text { R peak } \\
\text { if } z[n]<\text { Threshold } \rightarrow \text { NOT R peak } \\
\text { Threshold }=\alpha \gamma \text { PEAK }-(1-\alpha) \text { Threshold }
\end{gathered}
$$

\section{Experiment Setup}

For evaluation, we tested the wireless ECG patch by using MS-400 ECG simulator. At the first test, we generated ECG signal with rate of 40,60, 80, 100, and 120 BPM, then saw the heart rate display (Figure 4). The second test, we evaluated transition time $\left(T_{t r}\right)$, which is defined as how long the HRV reading displays the HRV in case of heart range changing. The changing was set to 60 to 80,80 to 100,100 to 120 , 120 to 100,100 to 80 , and 80 to $60 \mathrm{bpm}$. The faster the transition time, the better the ECG quality. For comparison, we used a commercial wireless ECG, KineticTM.

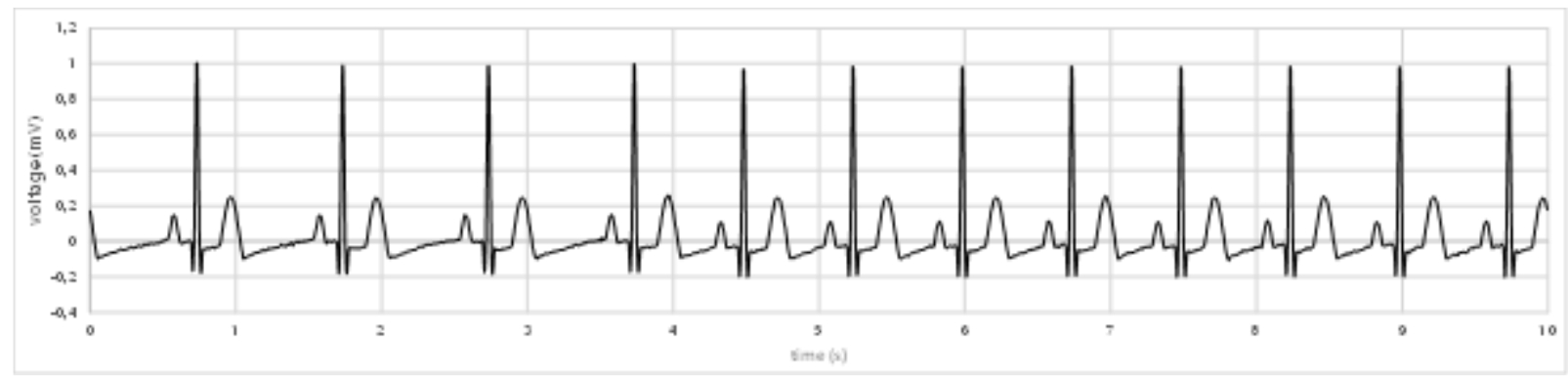

Figure 4: Sample of ECG captured signal 


\section{Result and Discussion}

\section{A. HRV Calculation}

The ECG simulator generated 40, 60, 80, 100, and 120 BPM. Kinetic and the proposed ECG patch then calculated the HRV in steady state condition, i.e. state where the HRV reading is stable. The results are presented in Table I. Cells with grey shading indicate BPM error. The table shows that the proposed ECG patch is more accurate in calculating HRV than Kinetic.

TABLE I. HRV CALCULATION IN STEADY STATE BY KINETIC AND THE PROPOSED ECG PATCH (IN BPM)

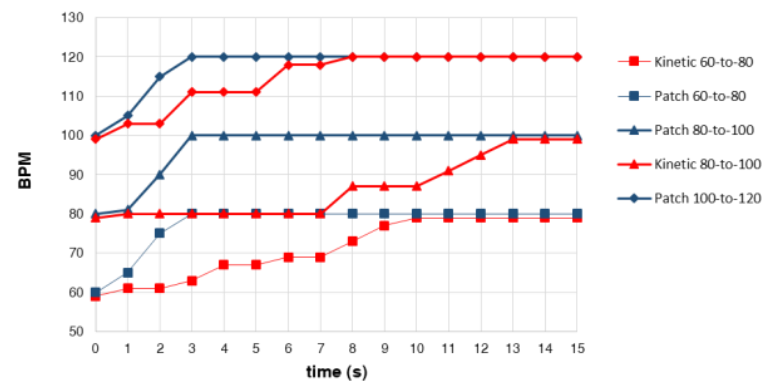

Figure 5: Transition time comparison: 60-to-80, 80-to-100, and 100-to120 BPM

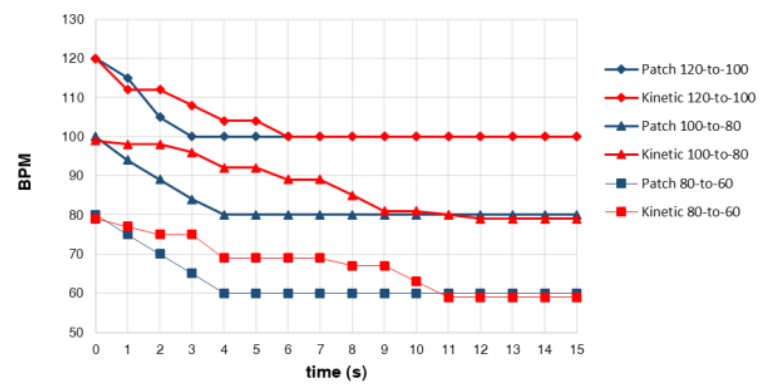

Figure 6: Transition time comparison: 120-to-100, 100-to-80, and 80-to60 BPM

TABLE II. TRANSITION TIME TEST RESULTS

\begin{tabular}{|l|c|c|}
\hline \multirow{2}{*}{ ECG Simulator } & \multicolumn{2}{|c|}{$T_{\text {tr }}(\mathrm{s})$} \\
\cline { 2 - 3 } & Kinetic $^{\mathrm{TM}}$ & Patch \\
\hline 60-to-80 BPM & 10 & 3 \\
\hline 80-to-100 BPM & 13 & 3 \\
\hline 100-to-120 BPM & 8 & 3 \\
\hline 120-to-100 BPM & 6 & 3 \\
\hline 100-to-80 BPM & 6 & 4 \\
\hline 80-to-60 BPM & 11 & 4 \\
\hline Average & 9.00 & 3.33 \\
\hline
\end{tabular}

\begin{tabular}{|c|c|c|}
\hline $\begin{array}{c}\text { ECG } \\
\text { Simulator }\end{array}$ & Kinetic $^{\mathrm{TM}}$ & Proposed ECG patch \\
\hline 40 & 40 & 40 \\
\hline 60 & 59 & 50 \\
\hline 80 & 79 & 80 \\
\hline 100 & 99 & 100 \\
\hline 120 & 120 & 120 \\
\hline
\end{tabular}

\section{B. Transition Time}

Transition time represents how long steady state HRV is reached since the heart rate changed. A fast transition time is important since heart attack may occurs in a short period e.g., several seconds. In addition, an ECG machine should have ability to calculate HRV in real time. Figure 5 demonstrates HRV measurement when the HRV was increasing from 60 to 80,80 to 100 , and 100 to $120 \mathrm{BPM}$ while Figure 6 demonstrates HRV measurement when the HRV was decreasing from 120 to 100,100 to 80 , and 80 to $60 \mathrm{BPM}$. The transition time $\left(T_{t r}\right)$ is presented in Table II. Based on results in Table II, the proposed ECG patch outperformed the Kinetic in term of $T_{t r}$, i.e. $3.33 \mathrm{~s}$ versus $9.00 \mathrm{~s}$, or 2.7 times faster averagely.

\section{Conclusions}

A proposed wireless ECG patch has been proposed and tested. The test results showed that the proposed ECG patch HRV had more accurate HRV calculation than a commercial product as well as had the transition time 2.7 times faster.

\section{Acknowledgment}

This work was supported by Indonesian Ministry of Research and Technology.

\section{References}

[1] E. J. Benjamin, M. J. Blaha, S. E. Chiuve, M. Cushman, S R. Das, R. Deo, S. D. d. Ferranti, J. Floyd, M. Fornage and C. Gillespie, "Heart Disease and Stroke Statistics-2017 Update: A Report From the American Heart Association," 2017.

[2] Pusdatin, "Info Data: Situasi Kesehatan Jantung," Jakarta, 2014.

[3] F. R. Hashim, Y. Januar, M. H. Mat, Z. I. Rizman and M. K. Awang, "Prediction of heart abnormality using MLP network," in AIP Conference Proceedings, 2018.

[4] M. R. Karaoğuz, E. Yurtseven, G. eAslan, B. G. Deliormanlı, ÖmerAdıgüzel, M. Gönen, K.-M. Li and E. N. Y1lmazb, "The quality of ECG data acquisition, and diagnostic performance of a novel adhesive patch for ambulatory cardiac rhythm monitoring in arrhythmia detection," Journal of Electrocardiology, vol. 54, pp. 28-35, 2019.

[5] S. Hartikainen, J. A. Lipponen, P. Hiltunen, T. T. Rissanen, I 
Kolk, M. P.Tarvainen, T. J.Martikainen, M. Castren, E.-S. Väliaho and H. Jäntti, "Effectiveness of the Chest Strap Electrocardiogram to Detect Atrial Fibrillation," The American Journal of Cardiology, vol. 123, no. 10, pp. 1643 1648, 2019.

[6] C. O. Avila, "Novel Use of Apple Watch 4 to Obtain 3-Lead Electrocardiogram and Detect Cardiac Ischemia," The Permanente Journal, vol. 23, pp. 99-102, 2019.

[7] T. Wu, J.-M. Redouté and M. Yuce, "A Wearable, LowPower, Real-Time ECG Monitor for Smart T-shirt and IoT Healthcare Applications," in Advances in Body Area Networks, Springer, Cham, 2019, pp. 165-173.

[8] I. H. Mulyadi, J. Haueisen and E. Supriyanto, "Practical aspects in surface biopotential electrode placement for smart clothing: A simulation study," in Proceedings of the First International Symposium of Biomedical Engineering (ISBE 2016), Depok, 2017.

[9] J. Pan and W. J. Tompkins, "A Real-Time QRS Detection Algorithm," IEEE Transactions on Biomedical Engineering, Vols. BME-32, no. 3, pp. 230-236, March 1985.

[10] D. K. Hasibuan and I. H. Mulyadi, "Real-Time Heart Rate Monitoring for Wearable Electrocardiography Using FilterBased and Peak Threshold Algorithms: A Comparative Study," Jurnal Integrasi, vol. 10, no. 2, pp. 54-58, October 2018. 